\title{
Iron-deficiency anaemia in calves
}

\author{
BY K. L. BLAXTER \\ Hannah Dairy Research Institute, Kirkhill, Ayr \\ G. A. M. SHARMAN \\ North of Scotland College of Agriculture, Inverness \\ AND A. M. MACDONALD \\ Royal Sick Children's Hospital, Glasgow \\ (Received 28th November 1956)
}

It is well known that milk is a poor source of dietary iron for almost all species. Experiments with calves restricted to a ration of whole milk have shown that anaemia develops after a time and can be prevented by the addition of $\mathrm{Fe}$ to the ration (Cannon, I93 I Knoop, Krauss \& Washburn, I935; Herman, I936). Haematological studies of calves in two herds at Beltsville, Maryland, showed that low concentrations of haemoglobin in the blood occurred under reasonably normal systems of calf management in which milk, concentrates and unlimited alfalfa (lucerne) hay were given (Thomas, Okamoto, Jacobsen \& Moore, 1954). Supplements of Fe given to moderately anaemic calves caused an increase in the blood haemoglobin. It may be emphasized that these calves had access to both grain and roughage: they were not restricted to milk alone.

Our experiments have been carried out to find whether in the herds of beef cattle of north Scotland anaemia, induced by Fe deficiency, was a practical problem. The husbandry of calves in this area has already been described (Sharman, 1954). The rearing system is characterized by a large daily intake of milk, and the intake of solid food is usually small. Further, the pens and stalls in which these calves are kept are usually of wood: there is little adventitious Fe the calves could ingest by licking or chewing their surroundings. Our experiments were of two types. Firstly, a small group of calves was reared at the laboratory on milk as the sole food, the development of anaemia being studied in detail to provide information on what to expect in mild anaemia and in severe anaemia. Secondly, extensive experiments were carried out on commercial farms in the north of Scotland.

\section{EXPERIMENTAL}

\section{Laboratory experiment}

Animals and housing. Six Ayrshire bull calves were housed in wooden pens with wooden slatted floors, and all screws and nails in construction countersunk. No bedding was allowed, and the pens were washed each day with tap water. Clinical records, including pulse rates, were taken daily. Each animal was killed after at least I8 weeks of experiment and was examined post mortem. 
Ration. Cows in late lactation were milked by machine and the milk was transferred, without cooling, into acid-washed glass bottles. The calves were given this milk as the sole food in plastic (Polythene) buckets, which were washed with distilled water after use. Values for the contamination of the milk by $\mathrm{Fe}$ when these precautions were used are given later. The diet of milk was supplemented daily with $25 \mathrm{mg} \alpha$-tocopheryl acetate and $5 \mathrm{ml}$. of a solution of $\mathrm{MgCl}_{2}$ supplying $200 \mathrm{mg}$ magnesium. Each calf was given $25 \mathrm{mg} \mathrm{Cu}$ as sulphate once monthly. Two calves (nos. 264 and 266) were given a daily supplement of $20 \mathrm{mg} \mathrm{Fe}$ as ferric citrate in aqueous solution. Four were given no Fe supplement; two of these (nos. 262 and 263) were given daily $2.5 \mathrm{~g} \mathrm{CaCO}_{3}$ as a supplement, since the findings of Greig ( 1952$)$ indicated that in mice the addition of $\mathrm{CaCO}_{3}$ to the diet led to anaemia that could be cured by $\mathrm{Fe}$ administration. No such effect of calcium supplementation was found in the calves. One calf given the Fe supplement (no. 266) was also given additional $\mathrm{CaCO}_{3}$. The milk intake was increased with age from 4 to 121 . daily. Records of refusals of milk were kept. After 134 days on the deficient ration, calf no. 262 was given $50 \mathrm{mg} \mathrm{Fe}$ daily in a curative test. The tissues of all the calves were analysed for Fe. Bone marrow and spleen were examined histologically.

Analytical methods. Fe was determined with the $\alpha-\alpha^{\prime}$-dipyridyl reagent. The methods for whole blood and serum were those of Ramsay (1952, 1953). The Fe content of milk and colostrum was determined on ashed material. Haemoglobin was determined as carboxyhaemoglobin in dilute ammonia solution by measuring its absorption at $54^{\circ} \mathrm{m} \mu$ spectrophotometrically. The $\mathrm{Fe}$ content of the whole blood was simultaneously determined by the method of Ramsay (1952, I953).

When the spectrophotometer reading was plotted against the $\mathrm{Fe}$ content of the whole blood, there was complete concordance over the range $14-48 \mathrm{mg} \mathrm{Fe} / \mathrm{I00} \mathrm{ml}$. which is equivalent to $4^{-1} 4 \mathrm{~g}$ haemoglobin/roo $\mathrm{ml}$. The Fe content of crystalline calf haemoglobin was found to be $0.34 \%$, and so both the $\mathrm{Fe}$ determinations and the spectrophotometric readings could be converted into $\mathrm{g}$ haemoglobin/100 ml. blood. Calcium and magnesium were determined by the method of Godden (1935). Potassium was determined in the red blood cells, after washing them with dilute sucrose solution, by the method of Barry \& Rowland (1953).

Haematological methods. Red cells and white cells were counted in a haemocytometer. The packed-cell volume was determined in haematocrit tubes centrifuged for I. $5 \mathrm{~h}$ at 3000 r.p.m. $(2200 \mathrm{~g})$. Blood films were fixed and stained with Leishmann's stain.

\section{Field experiment}

Fifteen farms co-operated in the field experiment and provided ninety-two calves for experimental purposes. On each farm the calves, which were Aberdeen Angus or Aberdeen Angus crosses, were allocated at birth, either to receive no treatment or to receive $35 \mathrm{mg}$ ferrous iron daily supplied as ferrous succinate. Late-born calves that had received treatment for less than $\mathrm{I}_{4}$ days were not included in the final analysis of results. Blood samples were taken from each calf at least twice in the course of the experiment, and the haemoglobin content, erythrocyte count, packed-cell volume and plasma protein were determined. The plasma protein was determined by the copper 
sulphate-specific gravity technique (Hawk, Oser \& Summerson, I947) and the results were used to find if haemoconcentration or haemodilution had taken place. Heparin was used as anticoagulant. Samples of blood were taken from a limited number of pairs of calves at 3 -week intervals throughout the experiment.

\section{RESULTS}

\section{Laboratory experiment}

The iron content of milk and colostrum. In order to find what precautions had to be taken in the laboratory experiment to minimize contamination of milk with Fe, milk samples were collected at various stages of the handling process. Typical results are given in Table $\mathrm{I}$.

\section{Table I. Contamination of milk with iron at various stages of milk handling}

$\begin{array}{ccc}\text { History of sample } & \overbrace{\text { Cow no. I }}^{\text {Fe content of milk (mg/l.) }} & \text { Cow no. 2 } \\ \text { (I) By hand milking after washing the udder } & 0.347 & 0.25 \mathrm{I} \\ \begin{array}{c}\text { and hands with distilled water } \\ \text { (2) After machine milking, normal method }\end{array} & 0.409 & 0.289 \\ \text { (3) After cooling (2) over a tinned-copper } & 0.439 & 0.334 \\ \quad \text { surface cooler } & 0.6 \mathrm{I} 4 & 0.483 \\ \text { (4) After storing (3) in a tinned milk churn } & 0.485 & 0.378 \\ \text { (5) After leaving (3) in a I gal. galvanized } & & \end{array}$

It appeared that machine milking with a milking plant constructed mainly of aluminium gave rise in this instance to a $15 \%$ increase in the amount of $\mathrm{Fe}$ in the milk. A series of seven tests gave for the $F e$ in hand-drawn milk mean values of 0.237 and in machine-drawn milk of $0.290 \mathrm{mg} / 1$. The mean difference of $0.053 \pm 0.010 \mathrm{mg} / 1$, representing an increase in $\mathrm{Fe}$ content of $22 \%$, was highly significant statistically. The process of cooling the milk caused a further increase, and churn storage increased the Fe content by $80 \%$. The normal process of calf-feeding in machine-milked herds in which milk is placed in a bucket with or without cooling would provide the calf with about $50 \%$ more $\mathrm{Fe}$ than its dam does.

It was noted that colostrum contained considerably more Fe than did milk from cows in mid to late lactation. Individual samples of uncontaminated colostrum contained as much as $0.86 \mathrm{mg} \mathrm{Fe} / 1$, the mean for ten samples from five cows being $0.51 \mathrm{mg} / \mathrm{l}$. Uncontaminated mid-lactation milk contained from 0.17 to $0.30 \mathrm{mg} / \mathrm{l}$. The high concentration of $\mathrm{Fe}$ in colostrum was partly due to the presence of cells. The deposit from centrifuging colostrum had invariably a high Fe content, even though no red blood cells were present. Red blood cells were present, however, in the sample containing $0.86 \mathrm{mg} / \mathrm{l}$.

The precautions observed in taking milk for the experiment were based on these results. Some Fe additional to that produced by the cow-about $25 \%$-was clearly present, but occasional analysis of the milk showed that the Fe content was seldom above $0.45 \mathrm{mg} / 1$. More usually the content was about $0.3 \mathrm{mg} / 1$. The value for normal 
milk obtained in these experiments was somewhat lower than those quoted in the literature for similar samples (Johnston, Gellman \& Strom, I948). It was distinctly lower than the values given in food tables, $0.7 \mathrm{mg} / \mathrm{kg}$ (United States Department of Agriculture, 1945) or $0.8 \mathrm{mg} / \mathrm{kg}$ (McCance \& Widdowson, 1946). Clearly considerable Fe contamination must have taken place in the commercial milk samples quoted in these food tables.

Clinical observations. The daily gains in body-weight of the six calves are given in Table 2.

Table 2. Gains (kg/day) in weight of the calves in the laboratory experiment

\begin{tabular}{|c|c|c|c|c|c|c|}
\hline \multirow[b]{2}{*}{ Period } & \multicolumn{2}{|c|}{ Calves given $\mathrm{Fe}$} & \multicolumn{4}{|c|}{ Calves not given $\mathrm{Fe}$} \\
\hline & No. 264 & No. 266 & No. 260 & No. $26 r$ & No. 262 & No. 263 \\
\hline Birth-6 weeks & $0.3 I$ & $0 \cdot 3^{8}$ & 0.34 & 0.35 & 0.30 & 0.40 \\
\hline 6-12 weeks & 0.66 & 0.69 & 0.49 & 0.57 & 0.45 & 0.42 \\
\hline 12-1 8 weeks & 0.72 & 0.59 & 0.10 & 0.07 & 0.34 & $0 \cdot 16$ \\
\hline 18-24 weeks & Killed & 0.59 & Killed & Killed & $\begin{array}{c}\text { Curative } \\
\text { test } \\
\text { Killed }\end{array}$ & $\begin{array}{l}0.19 \\
\text { Killed }\end{array}$ \\
\hline
\end{tabular}

During the first 6 weeks the calves given. Fe and those given none grew normally and at the same rate of 0.34 and $0.35 \mathrm{~kg} /$ day respectively. In the second 6-week period the control calves gained an average of $0.67 \mathrm{~kg} /$ day, and the deficient calves $0.49 \mathrm{~kg}$; in the third 6-week period the controls gained $0.66 \mathrm{~kg}$ and the deficient calves only $0.17 \mathrm{~kg}$. One control animal was killed at 18 weeks of age. The other was given the supplemented diet of whole milk for 30 weeks when the experiment was terminated, the calf then weighing $\mathrm{I} 37 \mathrm{~kg}$. The calves given no Fe were killed when severe clinical signs had developed. One calf (no. 26I) was killed when I6 weeks of age, one (no. 260) at 19 weeks, one (no. 263) at 23 weeks and one (no. 262) at 27 weeks.

The earliest sign of abnormality was a disinclination to drink the milk diet. Refusal of part of the day's allowance was common and clearly contributed to the slow gain in weight. Later, scours developed that were often refractory to treatment with antibiotics. Acidification of the milk with dilute hydrochloric acid was effective in reducing the diarrhoea. The mucous membranes of the mouth were very pale indeed at this stage, and the papillas of the tongue tended to be smooth compared with those of the control calves. The conjunctiva was markedly pale. Small crater-like ulcers appeared on the tongues and gums of two of the calves (nos. 26I and 260). Pulse rates taken at rest were the same in control and deficient calves. Attempts were made to produce similar circulatory stress in the calves by controlled exercise. This proved difficult, since the Fe-deficient calves were reluctant to move, whereas the calves receiving $\mathrm{Fe}$ were extremely boisterous. When the deficient calves were exercised successfully frothing at the mouth occurred, the pulse rate was increased to over $250 / \mathrm{min}$ and did not return to normal within $40 \mathrm{~min}$. Under similar conditions, the pulse rate of control calves did not exceed $200 / \mathrm{min}$ and had returned to the preexercise value in $20 \mathrm{~min}$. The final stage of the disease was a progressive anorexia: the animals were then killed. 
Haematological studies. The results of the haematological studies are summarized in Table 3 .

Table 3. Erythrocyte count, packed-cell volume and haemoglobin content of the blood of calves in the laboratory experiment

\begin{tabular}{|c|c|c|c|c|c|c|c|}
\hline \multirow{2}{*}{$\begin{array}{c}\text { Age } \\
\text { (weeks) }\end{array}$} & \multicolumn{2}{|c|}{ Calves given $\mathrm{Fe}$} & \multicolumn{4}{|c|}{ Calves not given $\mathrm{Fe}$} & \multirow{2}{*}{$\begin{array}{c}\text { Normal } \\
\text { calves } \\
\text { (Holman } \\
\text { r956) }\end{array}$} \\
\hline & No. 264 & No. 266 & No. 260 & No. $26 \mathrm{I}$ & No. 262 & No. 263 & \\
\hline \multicolumn{8}{|c|}{ Erythrocyte count $\left(\times 10^{6} \mathrm{~mm}^{3}\right)$} \\
\hline At birth & 10.24 & 10.05 & $9 \cdot 4 \mathrm{I}$ & $8 \cdot 28$ & $9 \cdot 34$ & 10.88 & $9 \cdot 8$ \\
\hline 6 & $9 \cdot 69$ & $9 \cdot 74$ & $9 \cdot 36$ & $7 \cdot 55$ & $8 \cdot 95$ & 10.45 & 9.4 \\
\hline I 2 & $8 \cdot 64$ & 10.02 & $9 \cdot 12$ & $7 \cdot 08$ & $8 \cdot 67$ & $8 \cdot 24$ & $9 \cdot 5$ \\
\hline I 8 & $9^{\circ} 01$ & 10.70 & 6.68 & $6 \cdot 89$ & $7 \cdot 24^{*}$ & $6 \cdot 60$ & - \\
\hline $23-24$ & - & $9 \cdot 20$ & - & $\ldots$ & $8 \cdot 82$ & $6 \cdot 35$ & 8.04 \\
\hline 27 & - & - & 一 & - & II 67 & - & - \\
\hline \multicolumn{8}{|c|}{ Packed-cell volume $(\%)$} \\
\hline At birth & $3^{8 \cdot 4}$ & $36 \cdot 7$ & $36 \cdot 0$ & $33 \cdot 8$ & $38 \cdot 2$ & $44 \cdot 8$ & $42 \cdot 5$ \\
\hline 6 & $32 \cdot 3$ & $33 \cdot 1$ & $26 \cdot 8$ & $25 \cdot 3$ & $26 \cdot 7$ & $36 \cdot 2$ & 29.0 \\
\hline 12 & $28 \cdot 4$ & $27 \cdot 1$ & 工 $5 \cdot 8$ & $18 \cdot 0$ & I9.9 & $23 \cdot 1$ & $34^{\circ} 1$ \\
\hline I 8 & $3 \mathrm{I} \cdot 8$ & $27 \cdot 5$ & r.9 & $16 \cdot 2$ & I $4 \cdot I^{*}$ & $17 \cdot 5$ & - \\
\hline $23-24$ & - & $27 \cdot 8$ & $14 \cdot 3$ & - & $26 \cdot 0$ & $13 \cdot 3$ & $36 \cdot 0$ \\
\hline 27 & 一 & - & 一 & - & $29 \cdot 3$ & - & - \\
\hline \multicolumn{8}{|c|}{ Haemoglobin (g/100 ml.) } \\
\hline At birth & I I 43 & $9 \cdot 79$ & 10.37 & 9.59 & II $\cdot 73$ & 12.69 & I $2 \cdot 9$ \\
\hline 6 weeks & $9 \cdot 72$ & $9 \cdot 35$ & $8 \cdot 84$ & $9 \cdot 43$ & $7 \cdot 73$ & $9 \cdot 64$ & 10.5 \\
\hline I 2 & $8 \cdot 05$ & $7 \cdot 72$ & $4 \cdot 3^{8}$ & $5 \cdot 59$ & 6.01 & 6.63 & II 7 \\
\hline 18 & $8 \cdot 4 \mathrm{I}$ & 7.90 & 3.47 & $4 \cdot 54$ & $3.99^{*}$ & $4 \cdot 38$ & - \\
\hline $23-24$ & - & $7 \cdot 80$ & 3.52 & - & 6.99 & $\begin{array}{l}4.30 \\
4 \cdot 17\end{array}$ & 10.6 \\
\hline 27 & - & - & - & - & $8 \cdot 91$ & - & - \\
\hline
\end{tabular}

The table shows that a severe anaemia was produced in the calves given no $\mathrm{Fe}$, and the single test with calf no. 262 showed that iron cured the anaemia. The packed-cell volume and haemoglobin content of the blood of the control calves fell with age, most of the fall occurring in the first 8 weeks of life. This fall has been observed by others and has been regarded as normal (Greatorex, I954; Holman, I956). The haemoglobin content of the blood of the control calves was, however, rather lower than expected from the results of Thomas et al. (1954), who found that in calves given $140 \mathrm{mg} \mathrm{Fe}$ daily the haemoglobin content of the blood was in the region of $10.0 \mathrm{~g} / 100 \mathrm{ml}$. Values of $8 \cdot 2-9.0 \mathrm{~g} / 100 \mathrm{ml}$. have been recorded by Holman (1956) in apparently healthy calves. There was little doubt, however, that the calves receiving no Fe supplement were grossly anaemic. The type of anaemia may be inferred from Table 4 . The volume of individual erythrocytes dropped by $50 \%$ in the deficient animals, but there was no fall in the concentration of haemoglobin in each corpuscle. The anaemia was thus of the microcytic, normochromic type, with a reduction in the number of blood corpuscles. Fe-deficiency anaemias in man are usually microcytic and hypochromic.

In Herman's ( 1936 ) experiments, in which three calves developed anaemia when given a ration of whole milk for 300-500 days, the haematocrit and haemoglobin values also suggest that the anaemia was normochromic. The packed-cell volumes 
obtained by Herman were, however, considerably greater than ours $(40-60 \%$ in normal calves and $25-40 \%$ in calves given whole milk).

Table 4. Mean erythrocyte volume, mean corpuscular haemoglobin, and mean corpuscular haemoglobin concentration of normal and anaemic calves at $18-24$ weeks in the laboratory experiment

\begin{tabular}{|c|c|c|c|}
\hline Calf no. & $\begin{array}{l}\text { Mean erythrocyte } \\
\text { volume } \\
\left(\mu^{3}\right)\end{array}$ & $\begin{array}{c}\text { Mean corpuscular } \\
\text { haemoglobin } \\
(\mu \mu \mathrm{g})\end{array}$ & $\begin{array}{l}\text { Mean corpuscular } \\
\text { haemoglobin } \\
\text { concentration } \\
\text { (g/roo ml. cells) }\end{array}$ \\
\hline \multicolumn{4}{|c|}{ Calves given $\mathrm{Fe}$} \\
\hline $\begin{array}{l}264 \\
266 \\
262^{*}\end{array}$ & $\begin{array}{l}35 \cdot 2 \\
30 \cdot 2 \\
25 \cdot 1\end{array}$ & $\begin{array}{l}0.93 \\
0.85 \\
0.76\end{array}$ & $\begin{array}{l}26 \cdot 4 \\
28 \cdot 1 \\
30 \cdot 4\end{array}$ \\
\hline \multicolumn{4}{|c|}{ Calves not given $\mathrm{Fe}$} \\
\hline $\begin{array}{l}260 \\
261 \\
262 \\
263\end{array}$ & $\begin{array}{l}19 \cdot 3 \\
23.5 \\
19.4 \\
20.9\end{array}$ & $\begin{array}{l}0.53 \\
0.65 \\
0.55 \\
0.66\end{array}$ & $\begin{array}{l}24 \cdot 6 \\
27 \cdot 8 \\
28 \cdot 2 \\
31 \cdot 3\end{array}$ \\
\hline \multicolumn{4}{|c|}{ * After curative test of 6 weeks. } \\
\hline
\end{tabular}

In Fig. I are compared the haemoglobin content, cell count and erythrocyte volume of the blood of the calves given no $\mathrm{Fe}$, of the calves given $20 \mathrm{mg} \mathrm{Fe}$ and of nine calves in the field experiment given $35 \mathrm{mg}$ Fe daily. Blood was taken from this last group only once every 3 weeks. It will be noted that the haemoglobin content of the blood of calves in the field given iron remained in the region of $10 \mathrm{~g} / 100 \mathrm{ml}$., whereas the values for the control calves were stabilized at about $8 \mathrm{~g}$. These results suggest that $20 \mathrm{mg} \mathrm{Fe}$ was insufficient for calves given virtually uncontaminated milk, growing rapidly and subject to weekly removal of about $25 \mathrm{ml}$. blood (equivalent to $\mathrm{r} \cdot 0 \mathrm{mg}$ $\mathrm{Fe} /$ day).

From Fig. I, it appears that Fe-deficiency anaemia in growing calves takes place in two stages. The initial fall in the haemoglobin content of the blood appears to be due to an increase in the proportion of microcytes. After II-I2 weeks the total number of erythrocytes per $\mathrm{mm}^{3}$ blood begins to decline. At no stage does there appear to be a reduction of haemoglobin concentration in the erythrocytes. It will be noted that, even in the healthy normal calves given $35 \mathrm{mg} \mathrm{Fe}$ in the field experiment, a decline in the volume of the erythrocytes took place during the first 7 weeks. This slow fall presumably reflects the death rate of large erythrocytes present in the calf at birth and their replacement by erythrocytes of normal size. This is no doubt the so-called physiological change noted by Holman ( 1956 ).

The microcytes seen in the later stages of the anaemia, that is when the haemoglobin concentration was below $5 \mathrm{~g} / \mathrm{r} 00 \mathrm{ml}$., showed marked poikilocytosis. Considerable care was taken to avoid fixation artifacts in making the films, and wet diluted mounts confirmed these findings. Cells of very bizarre shape were seen, a large number of very small cells and many with markedly uneven crenation. The number of leucocytes in the blood of all calves ranged from 7000 to $15,000 / \mathrm{mm}^{3}$. There were no differences that could be ascribed to an effect of treatment. 
Chemical composition of blood. The total Fe content of the blood was markedly reduced in the anaemic animals. The changes were exactly similar to those found for haemoglobin and are not reported further. There was no indication at any time of any significant difference between the two methods of assessing the amount of pigment. Serum Fe was initially high and fell in all calves to quantities too small to estimate with accuracy without taking larger quantities of serum than was thought advisable. The determinations were then discontinued. The concentration of $\mathrm{Ca}$ in the serum was unaffected by either the $\mathrm{CaCO}_{3}$ or the Fe supplement, but all calves given $\mathrm{CaCO}_{3}$
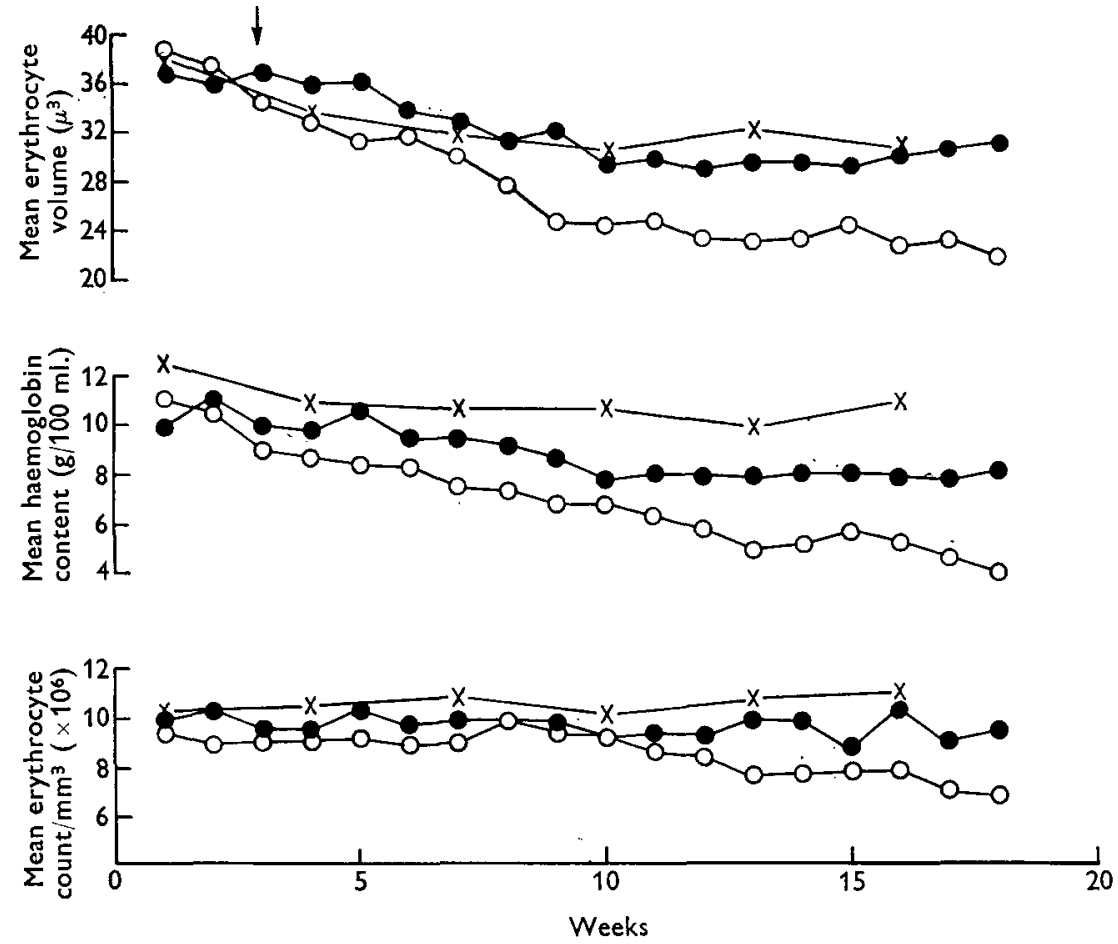

Fig. I. Mean erythrocyte volume $\left(\mu^{3}\right)$, mean haemoglobin content $(\mathrm{g} / 100 \mathrm{ml}$.) and mean erythrocyte count (count $\times 10^{6} / \mathrm{mm}^{3}$ ) in the blood of calves. $\times-\times$, nine calves in the field experiment given a supplement of $35 \mathrm{mg} \mathrm{Fe}$ daily; - two calves in the laboratory experiment given a supplement of $20 \mathrm{mg} \mathrm{Fe}$ daily; $\mathrm{O}-\mathrm{O}$, four calves in the laboratory experiment given no supplement.

showed a depression in the $\mathrm{Mg}$ content of the serum. Thus, at $\mathrm{I} 2$ weeks, in the three calves given no supplement of $\mathrm{CaCO}_{3}$ the serum- $\mathrm{Mg}$ concentrations were $1.93,2.55$ and $2.0 \mathrm{Img} / \mathrm{I} 00 \mathrm{ml}$. In the three calves given $\mathrm{CaCO}_{3}$, the concentrations were $\mathrm{I} \cdot 40$, $\mathrm{I} \cdot 46$ and $\mathrm{I} \cdot 2 \mathrm{Img} / \mathrm{roo} \mathrm{ml}$. The $\mathrm{Mg}$ concentration in the serum of these calves was restored by doubling the amount of supplementary $\mathrm{Mg}$ given.

Post-mortem findings. Nothing abnormal other than pallor of the muscles and organs was noted in any of the calves at post-mortem. Even in those dosed with $\mathrm{Fe}$ there was no indication that the muscles were darker in colour. This was particularly evident in the calf allowed to survive for 30 weeks; it still retained the muscle coloration characteristic of very young animals. The $\mathrm{Fe}$ contents of the tissues are given in 
Table 5. The normal values refer to Elvehjem \& Peterson's (1927) analyses. The calves given no $\mathrm{Fe}$ supplement had lower concentrations of $\mathrm{Fe}$ in the liver, kidney and heart, but there was no obvious gross depletion of the $\mathrm{Fe}$ in the muscles or in the spleen. The spleen Fe represents in part the $\mathrm{Fe}$ moiety of erythrocytes undergoing destruction, and gross depletion would hardly be expected in this organ. It will be noted that the iron contents of the liver and kidneys of the calves given additional $\mathrm{Fe}$ were lower than the values given as normal by Elvehjem \& Peterson (1927). This finding further suggests that the supplement of $20 \mathrm{mg} \mathrm{Fe}$ daily was not sufficient to remedy the Fe deficiency of cow's whole milk for the calf.

Table 5. Concentration ( $m g / 100 \mathrm{~g}$ dry matter) of iron in the tissues of calves in the laboratory experiment

\begin{tabular}{|c|c|c|c|c|c|c|}
\hline \multirow[b]{2}{*}{ Tissue } & \multicolumn{2}{|c|}{$\begin{array}{l}\text { Calves given } \\
20 \mathrm{mg} \mathrm{Fe}\end{array}$} & \multicolumn{3}{|c|}{ Calves not given $\mathbf{F e}$} & \multirow{2}{*}{$\begin{array}{c}\text { Normal values } \\
\text { for cattle } \\
\text { (Elvehjem \& } \\
\text { Peterson, I927) }\end{array}$} \\
\hline & No. 264 & No. 266 & No. 260 & No. 26r & No. 262 & \\
\hline Liver & $15 \cdot 4$ & I $8 \cdot 3$ & $x+6$ & $12 \cdot 0$ & I I 8 & $22 \cdot 0$ \\
\hline Kidney & $24 \cdot 3$ & $24 \cdot 2$ & $17 \cdot I$ & 14.7 & 14.7 & $29 \cdot 0$ \\
\hline Spleen & $41 \cdot 4$ & $36 \cdot 5$ & $37 \cdot 2$ & $27 \cdot 1$ & $42 \cdot 6$ & $38 \cdot 3$ \\
\hline Heart & $40 \cdot 6$ & $3 I \cdot 6$ & $23 \cdot 6$ & $20 \cdot 3$ & $22 \cdot 8$ & $46 \cdot 0$ \\
\hline Longissimus dorsi & 4.7 & 10.0 & 5.9 & 4.0 & $5 \cdot I$ & \\
\hline Rectus femoris & $4 \cdot 8$ & $6 \cdot 0$ & 4.9 & $5 \cdot 1$ & $5 \cdot 8$ & \\
\hline Supraspinatus & $\mathbf{1} 1 \cdot 0$ & $10 \cdot 1$ & $7 \cdot 5$ & $5 \cdot 9$ & $6 \cdot 4$ & $9-I 2$ \\
\hline Infraspinatus & 10.9 & $9 \cdot 7$ & 10.4 & $8 \cdot 1$ & $7 \cdot 1$ & \\
\hline
\end{tabular}

Histological findings. In the control calves, the bone marrow showed a normoblastic reaction and normal cellularity. No free $\mathrm{Fe}$ was found in the spleen. In the Fe-deficient calf no. 260, there was a slight normoblastic reaction of the marrow but no free $\mathrm{Fe}$ was present. In the other Fe-deficient calves, nos. $26 \mathrm{I}$ and $26_{3}$, the findings were similar. These results suggest that there were no abnormalities in the cellular reaction of the bone marrow, and certainly there was no cytological deficiency in the erythropoietic tissue. In calf no. 262, given additional $\mathrm{Fe}$, the marrow showed a good normoblastic reaction. The spleen contained large amounts of free Fe but none at all was present in the bone marrow. This finding suggests that the anaemia has some aspects in common with one occurring after haemolysis of the erythrocytes in vivo, since free Fe would then be found in the spleen.

\section{Field experiment}

The results of the experiments are summarized in Table 6.

Statistical analysis of the results showed that in the first age group the difference between the haemoglobin contents of the blood of calves given Fe and of those given none was significant at odds of $14: \mathrm{I}$. In the age group 40-80 days, the difference was significant at odds of only $4: \mathrm{I}$. It may therefore be concluded that a mild anaemia was present in the calves that responded to iron administration, being particularly apparent during the 40-80th days of life. The extent of the anaemia was a $10 \%$ depression of the blood haemoglobin.

The other figures in Table 6 show that the anaemia, though mild, was similar to the 
more severe anaemia produced by experimental Fe deficiency. Thus, the Fe supplement was without significant effect on the haemoglobin concentration in the erythrocytes, but had a statistically significant effect on the mean volume of the erythrocytes, so that the anaemia was microcytic and normochromic.

Table 6. Effect of $35 \mathrm{mg} \mathrm{Fe} /$ day on the haemoglobin content of blood, the haemoglobin concentration in the erythrocytes and the mean volume of the erythrocytes of calves in the farm experiment

\begin{tabular}{|c|c|c|c|c|c|c|c|}
\hline \multirow[b]{2}{*}{$\begin{array}{l}\text { Age of } \\
\text { calves* }\end{array}$} & \multirow{2}{*}{$\begin{array}{l}\text { No. of } \\
\text { pairs of } \\
\text { calves }\end{array}$} & \multicolumn{2}{|c|}{$\begin{array}{l}\text { Hb content of blood } \\
(\mathrm{g} / 100 \mathrm{ml} .)\end{array}$} & \multicolumn{2}{|c|}{$\begin{array}{l}\text { Mean erythrocyte } \\
\text { volume } \\
\left(\mu^{3}\right)\end{array}$} & \multicolumn{2}{|c|}{$\begin{array}{l}\text { Hb concentration } \\
\text { in erythrocytes } \\
(\mathrm{g} / \mathrm{r} 00 \mathrm{ml} .)\end{array}$} \\
\hline & & $\begin{array}{c}\text { No } \\
\text { supplemen }\end{array}$ & $\underset{\text { upplement }}{\mathrm{Fe}}$ & $\begin{array}{c}\text { No } \\
\text { supplement }\end{array}$ & $\underset{\mathrm{Fe}}{\mathrm{Fupplement}}$ & $\begin{array}{c}\text { No } \\
\text { supplemen }\end{array}$ & $\frac{\mathrm{Fe}}{\text { supplement }}$ \\
\hline $20-40$ days & $\mathrm{r} 6$ & IO.II & 10.98 & $32 \cdot 72$ & $34 \cdot 30$ & $30 \cdot 37$ & 30.26 \\
\hline $40-80$ days & 27 & $9 \cdot 28$ & 10.24 & 30.23 & 33.50 & $29 \cdot 71$ & $29 \cdot 55$ \\
\hline Over 80 days & 8 & $11 \cdot 00$ & I I $\cdot 27$ & 30.83 & $32 \cdot 95$ & $29 \cdot 95$ & $29 \cdot 60$ \\
\hline
\end{tabular}

* Some pairs of calves occur in each group, when aged 20-40 days, and again when aged 40-80 or over 80 days.

More detailed analysis of the results, however, indicated that there were large differences in the haemoglobin concentrations in the blood of different calves even when they were given additional Fe. This is shown in Fig. 2 where the results for thirty-seven calves aged 40-80 days given iron are compared with those for forty-one calves given no supplement. The results are not paired: on some farms the pairs diverged in age by more than 20 days and in the results presented in Table 6 these were discarded in making the statistical analysis. The results indicate, however, that, although $\mathrm{Fe}$ administration reduced the proportion of calves with haemoglobin concentrations of less than $8.0 \mathrm{~g} / \mathrm{100} \mathrm{ml}$. from 44 to $13 \%$, some calves, even when given supplements of $35 \mathrm{mg} \mathrm{Fe}$ daily, failed to maintain haemoglobin concentrations of $8.0 \mathrm{~g} / \mathrm{I} 00 \mathrm{ml}$. blood. This peculiarity was clearly associated with particular farms. Thus, on one farm the haemoglobin content of supplemented calves aged 40-80 days averaged I4.I, whereas on another it averaged $8.8 \mathrm{~g} / 100 \mathrm{ml}$. The analysis of variance given in Table 7 shows that differences between farms were highly significant, but there was no indication from the results as a whole that the animals on farms with

Table 7. Analysis of variance of the haemoglobin content $(\mathrm{g} / \mathrm{r} 00 \mathrm{ml}$.) of blood of calves in the farm experiment

\begin{tabular}{|c|c|c|c|}
\hline Component & $\begin{array}{l}\text { Degrees of } \\
\text { freedom }\end{array}$ & $\begin{array}{c}\text { Estimated } \\
\text { variance }\end{array}$ & $e^{2 z}$ \\
\hline Total & 53 & - & 一 \\
\hline Between farms & II & 10.478 & $3.90^{* *}$ \\
\hline Between pairs on farms & 15 & $2 \cdot 684$ & \\
\hline Between total pairs & 26 & 5.982 & - \\
\hline Effect of Fe dosage & $\mathrm{x}$ & 12.317 & $6.05^{*}$ \\
\hline Interaction, farms $\times$ dosage & I 1 & $2 \cdot 262$ & $I \cdot I I$ \\
\hline Error term & 15 & 2.034 & \\
\hline
\end{tabular}


the more anaemic calves responded more to Fe therapy. In Fig. 3, the mean cell volume of untreated calves is plotted against the haemoglobin content of the blood, both being measured between the 4oth and 6oth day, and farm means being used for this purpose. On the same graph terminal values for deficient calves in the laboratory
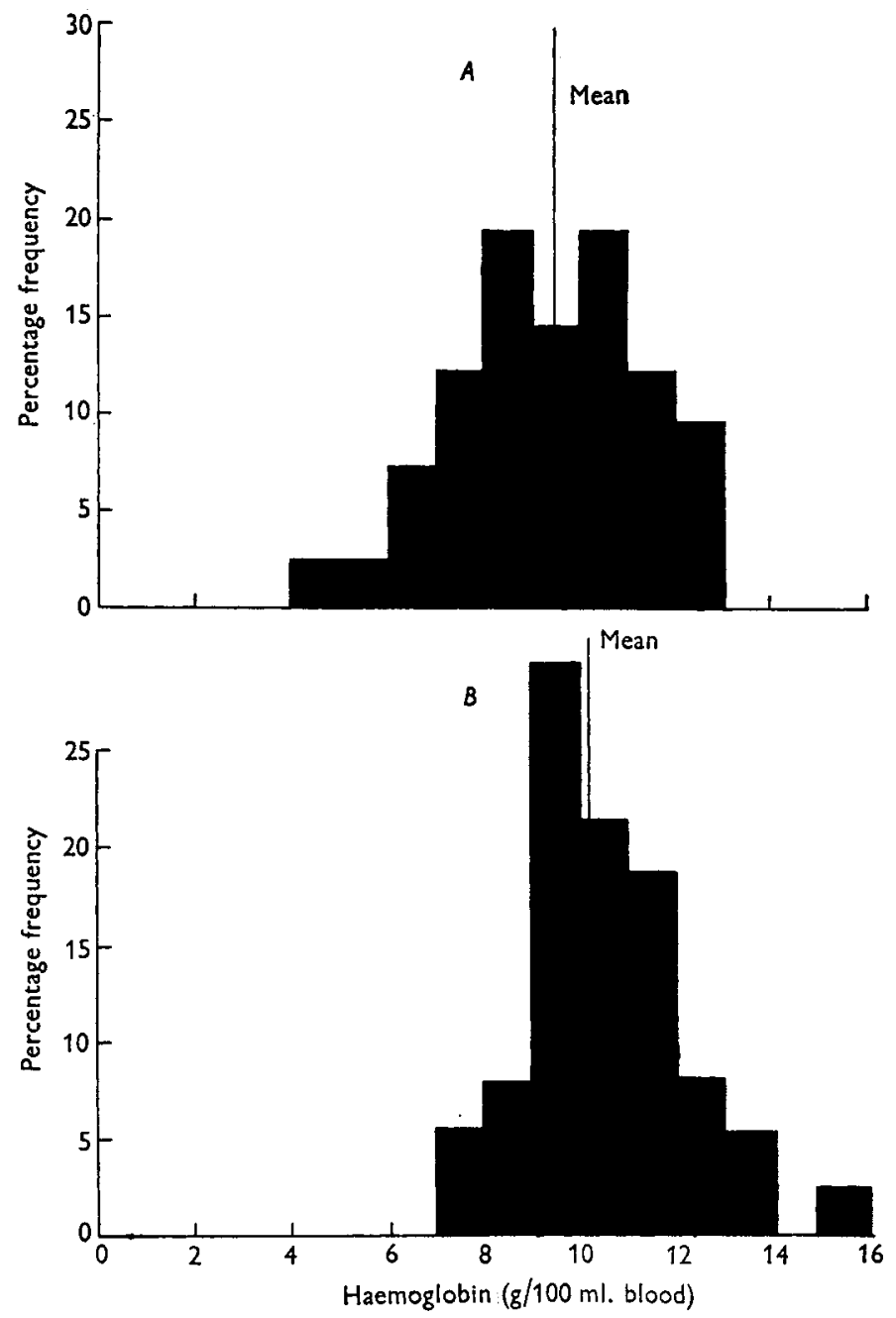

Fig. 2. Percentage frequency distribution of the haemoglobin content of the blood of $(A)$ forty-one calves aged 40-80 days given no supplement, and $(B)$ thirty-seven similar calves given an iron supplement.

experiment are plotted. It appears that the animals on farms with calves having a low blood haemoglobin content also had a low mean cell volume, which suggests that the mild anaemia on these farms was probably of the type that responds to iron dosage. In view of the fact that $20 \mathrm{mg} \mathrm{Fe}$ were not sufficient to maintain cell volume and haemoglobin concentration in the blood of calves in the laboratory experiment, it is possible that calves on many of these farms required more $\mathrm{Fe}$ than $35 \mathrm{mg}$ daily. 


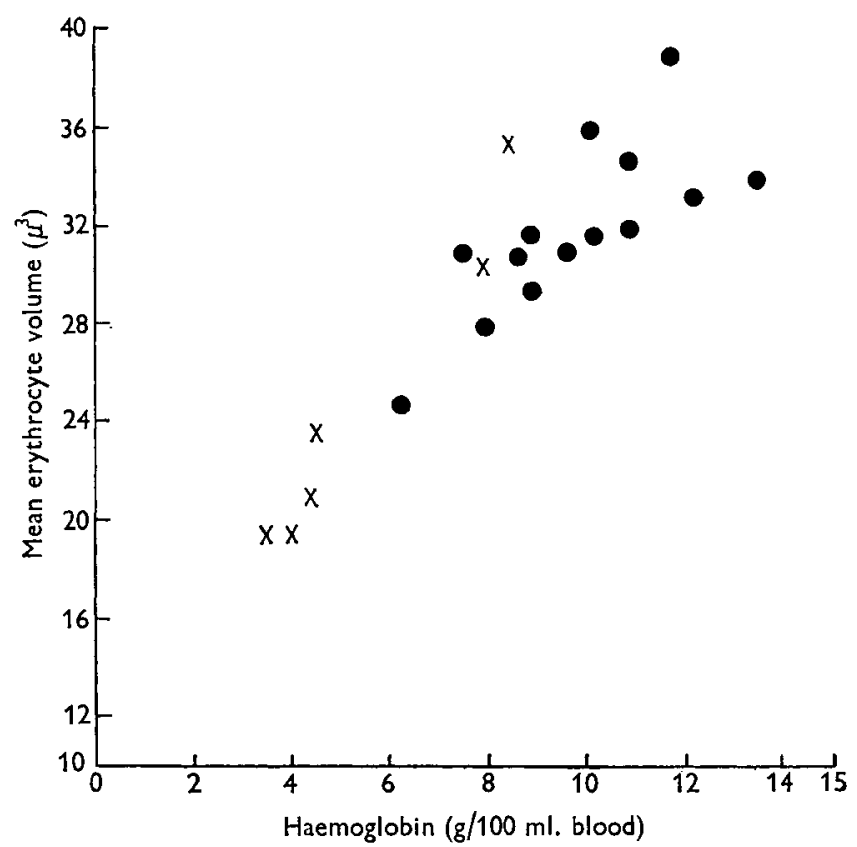

Fig. 3. Relation between the haemoglobin content of the blood and the mean volume of the erythrocytes of calves. mean values for untreated calves on the fourteen farms; $x$, values for individual calves in the laboratory experiment.

\section{DISCUSSION}

There is little doubt that Fe-deficiency anaemia was produced in the experimental calves at the laboratory, and that a mild Fe-deficiency anaemia exists under the normal conditions of calf rearing on farms in the north of Scotland. The anaemia is microcytic, normochromic and poikilocytic, it is associated with a normoblastic bone marrow and it responds to $\mathrm{Fe}$ therapy. The evidence suggests that $20 \mathrm{mg} F$ daily for experimental calves or $35 \mathrm{mg} F$ daily for calves on commercial farms is not sufficient to maintain normal haemoglobin levels. It is remarkable that under experimental conditions, when the unsupplemented calves received only $2 \cdot 0-4.0 \mathrm{mg} \mathrm{Fe}$ in their daily ration and were subject once weekly to blood sampling and the removal of $25 \mathrm{ml}$. blood containing approximately 7-10 $\mathrm{mg} \mathrm{Fe}$, or I mg Fe daily, anaemia should have taken so long to develop. Nothing grossly abnormal could be detected during the first 6 weeks of life, and it was only after 2 months of experiment that differences between control calves and deficient calves became obvious. During this period, the calves had increased in body-weight by nearly $80 \%$.

Bianca (1956), working with calves kept under conditions similar to ours, has shown that the total erythrocyte mass of the body is approximately $\mathrm{r} \cdot 85 \%$ of body-weight. On the assumption that the normal haemoglobin content of the erythrocyte is $30 \%$ and the $\mathrm{Fe}$ content of haemoglobin $0.34 \%$, the requirement of $\mathrm{Fe}$ for haemoglobin synthesis per $\mathrm{kg}$ gain in body-weight would be $19 \mathrm{mg}$. To this must be added the $\mathrm{Fe}$ contained in Fe-containing enzymes in the tissue cells and in the myoglobin of muscle. 
This Fe may be estimated at approximately $20 \mathrm{mg} / \mathrm{kg}$ body-weight. The total requirement of a calf gaining I kg daily, apart from any need to store Fe in the liver or extrahepatic tissue, is thus approximately $40 \mathrm{mg} /$ day. If normal storage of the element is included, and the Fe content of tissue assessed at $15^{-20} \mathrm{mg} / 100 \mathrm{~g}$ dry matter, the requirement for $\mathrm{Fe}$ needs to be increased to $50-60 \mathrm{mg}$ daily.

The calves given milk alone and growing at the rate of about $400 \mathrm{~g} /$ day thus required about $\mathrm{r} 6-24 \mathrm{mg} \mathrm{Fe}$ and received 2-4 $\mathrm{mg}$. The calves given an Fe supplement growing at a higher rate of $500 \mathrm{~g}$ daily required $20-30 \mathrm{mg}$ and received $22-24 \mathrm{mg}$ daily. The absorption and retention of dietary Fe can hardly be complete. Thus, in human babies, the maximal retention of dietary Fe noted by Stearns \& Stinger (1937) was only $24 \%$. If the same is true of the calf, requirements are probably in the region of $100 \mathrm{mg} \mathrm{Fe}$ daily.

It appears from the above calculations that the animals given Fe supplements in the laboratory experiment did not receive sufficient to meet their requirements and that the fall in cell volume and haemoglobin content of their blood may be referred to a dietary lack of Fe. The same is very likely the reason for the low haemoglobin concentrations in calves on some farms in the field, even when they were given $35 \mathrm{mg}$ $\mathrm{Fe}$ daily. The fact that anaemia takes so long to develop in calves given diets low in $\mathrm{Fe}$, compared with piglets, in which anaemia rapidly develops (Venn, McCance \& Widdowson, 1947), must reflect both the smaller liver stores of the element in the pig, as suggested by McCance \& Widdowson (I95I), and the fact that the relative growth of the suckling pig is much greater than that of the calf. In 2 months, the weight of a piglet increases tenfold: a calf will normally have increased in weight by only 6o$80 \%$ in that time (Brody, 1945; Braude, 1954).

\section{SUMMARY}

r. Iron-deficiency anaemia was produced in four calves under laboratory conditions on a milk diet supplemented with magnesium, copper and tocopherol. Two calves acted as controls, and received daily a supplement of $20 \mathrm{mg} \mathrm{Fe}$ as the citrate.

2. The anaemia was microcytic and normochromic and was associated with poikilocytosis and a normoblastic reaction of the bone marrow. Clinically, the anaemic calves showed poor gains of weight, an inability to withstand circulatory strain, atrophy of the papillas of the tongue and loss of appetite. The anaemia responded to $\mathrm{Fe}$ administration in the one calf to which the treatment was given.

3. A field experiment involving fifteen farms and forty-six pairs of suckling beef calves showed that daily dosage with $35 \mathrm{mg}$ of $\mathrm{Fe}$ as the succinate resulted in a significant increase in the haemoglobin content of the blood and an increase in the mean cell volume.

4. It was shown that on different farms there exist different haemoglobin contents in the blood of calves and that calves with low haemoglobin concentrations usually have smaller mean cell volumes. It is shown that this 'physiological anaemia' is of the same type as Fe-deficiency anaemia.

5. Evidence is presented to show that a supplement of $20 \mathrm{mg} \mathrm{Fe}$ daily is not 
sufficient for a calf aged $\mathbf{I}-4$ months receiving milk as the sole diet, and it is suggested that the requirement is nearer roo $\mathrm{mg}$ daily. The daily iron intake in milk is usually 2-4 mg.

\section{REFERENCES}

Barry, J. M. \& Rowland, S. J. (1953). Biochem. F. 53, 213.

Bianca, W. (1956). Private communication.

Braude, R. (1954). In Progress in the Physiology of Farm Animals. Vol. I. [J. Hammond, editor.] London: Butterworths Scientific Publications.

Brody, S. (1945). Bioenergetics and Growth. New York: Reinhold Publishing Corp.

Cannon, C. Y. (1931). Res. Bull. Ia agric. Exp. Sta. no. 136.

Elvehjem, C. A. \& Peterson, W. H. (1927). F. biol. Chem. 74, 433.

Godden, W. (1935). Tech. Commun. Bur. Anim. Nutr., Aberd., no. 9.

Greatorex, J. C. (1954). Brit. vet. F. 110, 120.

Greig, W. A. (1952). Brit. F. Nutr. 6, 280.

Hawk, P. B., Oser, B. L. \& Summerson, W. H. (1947). Practical Physiological Chemistry. Toronto: Blakiston Co.

Herman, H. A. (1936). Res. Bull. Mo. agric. Exp. Sta. no. 245.

Holman, H. H. (1956). Brit. vet. F. I12, 91.

Johnston, F. A., Gellman, N. \& Strom, J. (I948). F. biol. Chem. I75, 343.

Knoop, C. E., Krauss, W. E. \& Washburn, R. G. (1935). F. Dairy Sci. 18, 337.

McCance, R. A. \& Widdowson, E. M. (1946). Spec. Rep. Ser. med. Res. Coun., Lond., no. 235, and ed.

McCance, R. A. \& Widdowson, E. M. (195 I). F. Physiol. rr2, 450.

Ramsay, W. N. M. (1952). Biochem. 7. 51, 289.

Ramsay, W. N. M. (1953). Biochem. F. 53, 227.

Sharman, G. A. M. (1954). Vet. Rec. 66, 275.

Stearns, G. \& Stinger, D. (1937). F. Nutr. 13, 127.

Thomas, J. W., Okamoto, M., Jacobsen, W. C. \& Moore, L. A. (1954). F. Dairy Sci. $37,805$.

United States Department of Agriculture (1945). Misc. Publ. U.S. Dep. Agric. no. 572.

Venn, J. A. J., McCance, R. A. \& Widdowson, E. M. (1947). F. comp. Path. 57, 3 I4. 